\title{
Kajian Pengaruh Variasi Material Terhadap Kuat Tekan Beton
}

\author{
${ }^{1}$ Suhendra \\ ${ }^{1}$ Prodi teknik Sipil Unbari \\ suhendra_domas@yahoo.com
}

\begin{abstract}
Abstrak
Kualitas Agregat sangat berpengaruh pada kekuatan beton yang dihasilkan. Agregat kasar maupun agregat halus memiliki karakteristik bermacam-macam yang diidentifikasikan dari hasil uji laboratorium. Penelitian ini bertujuan mengkaji penggunaan berbagai macam agregat untuk suatu mutu beton. Agregat kasar dan agregat halus yang digunakan diperoleh dari lokasi terdekat dengan pekerjaan yang akan dilaksanakan. Mutu beton yang ditinjau adalah K-125, K-175 dan K-225. Agregat kasar yang digunakan adalah batu pecah ukuran 1-2, batu pecah ukuran 2-3 dan koral. Agregat halus yang digunakan untuk masing-masing agregat kasar juga berbeda. Hasil pemeriksaan menunjukkan bahwa agregat kasar koral tidak memenuhi gradasi butir agregat kasar beton. Sedangkan agregat halus tidak memenuhi gradasi butir agregat halus beton untuk ketiga jenis yang digunakan. Hasil uji kuat tekan beton menunjukkan penggunaan agregat kasar batu pecah ukuran 2-3 dan agregat kasar koral memberikan nilai kuat tekan beton rata-rata yang disyaratkan untuk semua mutu beton yang direncanakan. Sedangkan beton yang menggunakan agregat kasar batu pecah ukuran 1-2 hanya memenuhi kuat tekan yang ditentukan, namun tidak memenuhi kuat tekan ratarata yang disyaratkan.
\end{abstract}

Kata kunci: Agregat, Beton, Kuat Tekan

\begin{abstract}
Aggregate quality is very influential on the strength of the resulting concrete. Both coarse and fine aggregates have various characteristics identified from laboratory test results. This study aims to examine the use of various aggregates for a quality of concrete. The coarse aggregate and the fine aggregate used are obtained from the nearest location to the work to be performed. The quality of the concrete reviewed is $K-125, K-175$ and $K-225$. The coarse aggregates used are 1 2 size (in $\mathrm{cm}$ ), 2-3 size (in $\mathrm{cm}$ ) crushed aggregate and coral. The fine aggregates used for each of the coarse aggregates are also different. The results showed that the coral aggregate did not meet the gradations of concrete aggregate. While the fine aggregate does not meet the gradation of concrete aggregate for the three types used. The concrete compressive strength test results show the use of coarse aggregates of 2-3 size of crushed and coarse aggregate of corals giving the average compressive strength value required for all planned concrete strength. While concrete using coarse aggregates of rocks of size 1-2 only meet the specified compressive strength, but does not meet the required compressive strength.
\end{abstract}

Key words: Aggregates, concrete, compressive strength

\section{PENDAHULUAN}

Beton merupakan massa padat hasil campuran dari semen hidrolik (Portland cement), agregat kasar, agregat halus dan air dengan atau tanpa bahan 
tambahan. Kekuatan beton biasanya dicirikan dari kuat tekannya. Kekuatan beton tergantung dari berbagai faktor.

Material pembentuk beton berasal dari banyak sumber. Kualitasnya pun berbeda-beda. Penelitian ini bertujuan untuk mengkaji hubungan antara kualitas material pembentuk beton dengan kuat tekannya. Material-material yang masuk dalam rentang spesifikasi teknis masing-masing digunakan digunakan untuk mendapatkan mutu beton yang sama. Hasil Perencanaan campuran beton yang dilakukan di Laboratorium Teknik Universitas Batanghari digunakan sebagai data penelitian ini.

Penelitian ini bermaksud untuk mengkaji pengaruh kualitas material pembentuk beton dengan kuat tekannya. Material pembentuk disini adalah agregat kasar dan agregat halusnya. Agregat yang digunakan adalah agregat yang tersedia di lokasi rencana pembuatan beton. Sehingga dalam pelaksanaannya, kondisi dan kualitas agregat yang digunakan adalah seperti yang tersedia di lokasi tersebut.

Penelitian ini sejalan dengan pemeriksaan material yang dilakukan di Laboratorium Teknik Unbari untuk PT Waskita Karya (persero) pada pekerjaan pembetonan tower Saluran Udara Tegangan Ekstra Tinggi (Sutet) Paket 2 Aur Duri, Jambi - Pranap, Riau.

Berdasarkan hal tersebut, ditetapkan 3 (tiga) mutu beton yang ditinjau dengan 3 (tiga) macam agregat kasar dan agregat halus yang digunakan dalam penelitian ini.

Benda uji berupa kubus berukuran $15 \times 15 \times 15 \mathrm{~cm}^{3}$. Benda uji terdiri atas 3 (tiga) mutu yakni K125, K175 dan K225. Sedangkan agregat kasar yang digunakan adalah batu pecah ukuran 1-2 (1 sampai $2 \mathrm{~cm}$ ), 2-3 serta koral.

Adapun tujuan penelitian ini adalah:

1. Mengetahui kualitas mutu agregat pembuat beton yang direncanakan.

2. Membandingkan hasil uji material dengan standar spesifikasi menurut acuan SNI.

3. Mendapatkan hubungan antara kualitas material dengan kuat tekan untuk mutu beton rencana.

Bahan - bahan pembentuk beton yang digunakan dipilih sesuai dengan standar yang digunakan. Bahan - bahan dasar beton seperti semen, agregat halus, agregat kasar dan air dipilih dengan mempertimbangkan lokasi material yang mudah didapat dengan kualitas yang terjamin (American Society for Testing and Materials).

\section{Rancangan Campuran Beton}

Tujuan perancangan campuran beton adalah untuk menentukan proporsi bahan baku beton yaitu semen, agregat halus, agregat kasar dan air. Proporsi bahan-bahan penyusun beton ini ditentukan melalui sebuah perancangan beton. Hal ini dilakukan agar proporsi campuran dapat memenuhi syarat teknis secara ekonomis.

Dalam rancangan campuran beton ada beberapa metode rancangan yang dikenal dan banyak digunakan antara lain :

- Metode SK SNI T - 15 - 1990 - 03

- Metode SNI 03-2834-2000 yang identik dengan Metode DOE

- (Department Of Environment)

- Metode ACI (American Concrete Institute) 


\section{Kuat Tekan Hancur Beton}

Secara umum, kuat tekan hancur beton diperoleh dengan mengacu pada nilai kuat tekan benda uji berbentuk silinder ukuran $100 \mathrm{~mm}$ x $200 \mathrm{~mm}$, atau silinder ukuran $150 \mathrm{~mm}$ x $300 \mathrm{~mm}$ atau kubus $150 \mathrm{~mm} \times 150 \mathrm{~mm} \times 150 \mathrm{~mm}$ oleh beban uniaksial (beban ditekan dari atas) ( Tri Mulyono, 2005 ).

Pengertian nilai kuat tekan adalah perbandingan beban aksial maksimum pada saat benda uji mengalami keruntuhan dengan luas penampang benda uji.

\section{METODE PENELITIAN}

Material berupa agregat kasar dan halus disediakan oleh PT. Waskita Karya (persero). Sedangkan air pencampur digunakan air PDAM Tirta Mayang Jambi. Benda uji berbentuk kubus ukuran $150 \mathrm{~mm}$ x $150 \mathrm{~mm}$ x $150 \mathrm{~mm}$. Umur pengujian benda uji adalah 7, 14 dan 28 hari. Namun untuk penelitian ini, yang dianalisis adalah kuat tekan umur 28 hari.

Pengujian kuat tekan mengacu pada SNI 03-1974-1990 dan ASTM C 39M. Perencanaan campuran beton untuk uji kuat tekan mengacu pada SNI 032834-2002. Meskipun material yang diuji tidak memenuhi spesifikasi, namun tetap digunakan sebagai bahan pembuat beton. Hal ini sesuai dengan kajian bahwa benda uji dibuat berdasarkan material yang tersedia di lokasi. Alat uji yang digunakan tersedia di Laboratorium Fakultas Teknik Unbari.

\section{HASIL PENELITIAN DAN ANALISIS}

Hasil uji material menunjukkan bahwa tidak semua item kualitas material dipenuhi oleh agregat halus maupun agregat kasar. Sebagaimana terlihat pada tabel berikut, baik agregat kasar ukuran 1-2 cm, ukuran 2-3 $\mathrm{cm}$ ataupun koral dan agregat halus, gradasinya tidak sepenuhnya masuk dalam kriteria agregat untuk beton.

Tabel 1. Ringkasan hasil Pengujian Agregat Kasar

\begin{tabular}{|c|c|c|c|c|c|c|c|}
\hline \multirow[b]{2}{*}{ No } & \multirow{2}{*}{\multicolumn{2}{|c|}{ MACAM PENGUJIAN }} & \multicolumn{3}{|c|}{ HASIL } & \multirow[b]{2}{*}{$\begin{array}{l}\text { SYARAT } \\
\text { MUTU }\end{array}$} & \multirow{2}{*}{$\begin{array}{l}\text { METODE UJI/ } \\
\text { STANDARD }\end{array}$} \\
\hline & & & AK $1-2$ & AK 2-3 & $\begin{array}{c}\text { AK } \\
\text { Koral }\end{array}$ & & \\
\hline \multirow[t]{6}{*}{1} & \multirow{2}{*}{\multicolumn{5}{|c|}{ Berat Jenis Gr/cc }} & & \\
\hline & & & & & & Minimum & \\
\hline & \multicolumn{2}{|l|}{ - BJ Kering / Oven Dry (gr/cc) } & 2,557 & 2,660 & 2,514 & 2,5 & AASHTO T-85-74 \\
\hline & \multicolumn{2}{|l|}{ - BJ JKP / SSD (gr/cc) } & 2,572 & 2,670 & 2,539 & Snopifiknoi & (ASTM C-127-68) \\
\hline & \multirow{2}{*}{\multicolumn{2}{|c|}{$\begin{array}{l}\text { - BJ Semu/Apparent (gr/cc) } \\
\text { - Peresapan / Absorption (\%) }\end{array}$}} & 2,597 & 2,687 & 2,580 & Spesitikası & \\
\hline & & & 0,604 & 0,371 & 1,020 & & \\
\hline 2 & \multicolumn{2}{|c|}{$\begin{array}{l}\text { Ketahanan Agregat thdp Keausan / } \\
\text { Abrasi Test (\%) }\end{array}$} & 25,15 & 21,75 & 33,55 & Max. $40 \%$ & ASTM C-31-69 \\
\hline 3 & \multicolumn{2}{|c|}{$\begin{array}{l}\text { Ketahanan Agregat thdp Tumbukan / } \\
\text { Inpact Test (\%) }\end{array}$} & 10,77 & 13,39 & 18,44 & $10-20 \%$ & B.S 812.90 \\
\hline \multirow[t]{3}{*}{4} & \multirow{3}{*}{\multicolumn{2}{|c|}{$\begin{array}{l}\text { Berat Isi / Unit Weight : } \\
\text { - Lepas / Gembur (Kg/Liter) } \\
\text { - Padat (kg/Liter) }\end{array}$}} & & & & & \multirow{3}{*}{$\begin{array}{c}\text { ASTM C-29/29M- } \\
91 \mathrm{a}\end{array}$} \\
\hline & & & 1,388 & 1,475 & 1,425 & & \\
\hline & & & 1,531 & 1,611 & 1,467 & & \\
\hline 5 & \multicolumn{2}{|l|}{ Kadar Lumpur (\%) } & 0,717 & 0,565 & 0,708 & Max. $10 \%$ & ASTM C-142-97 \\
\hline 6 & \multicolumn{2}{|l|}{ Bahan yang Lolos \#200 (\%) } & 0,959 & 1,535 & 1,370 & Max. $1 \%$ & ASTM C 117-97 \\
\hline 7 & \multicolumn{2}{|l|}{ Kadar Air (\%) } & 1,686 & 1,876 & 1,920 & & ASTM C566-89 \\
\hline \multirow[t]{7}{*}{8} & \multicolumn{3}{|l|}{ Analisa Saringan } & \multicolumn{2}{|c|}{ Persen Lolos Lolos } & & \\
\hline & Ukuran Saringan & $1 "$ & 100,00 & 100,00 & 100,00 & 100 & $\begin{array}{l}\text { ASIM label } 2.5 \\
\text { Syarat Batas }\end{array}$ \\
\hline & & $3 / 4 "$ & 92,97 & 100,00 & 100,00 & $95-100$ & $\begin{array}{l}\text { syarat Batas } \\
\text { Gradasi Agaregat }\end{array}$ \\
\hline & & $1 / 2 "$ & 33,56 & 33,12 & 98,64 & $25-60$ & $\begin{array}{c}\text { Gradası Aggregat } \\
\text { Kasar }\end{array}$ \\
\hline & & $3 / 8 "$ & 8,41 & 2,95 & 94,86 & $0-10$ & \\
\hline & & No.4 & 0,00 & 0,00 & 46,38 & $0-5$ & \\
\hline & Modulus Kehalusan & & 7,65 & 7,65 & 5,60 & $5-7$ & \\
\hline
\end{tabular}

Sumber: Hasil penelitian, 2017 
Tabel 1 memperlihatkan bahwa pada umumnya syarat indeks agregat kasar terpenuhi, kecuali gradasi butiran. Agregat kasar koral, sebagian gradasi butirannya tidak memenuhi pesyaratan ASTM C33. Gradasi koral cenderung seragam. Selain itu, material halus yang lolos saringan \#200 untuk agregat 2-3 dan koral melebihi ambang batas spesifikasi. Modulus kehalusan butir agregat 1-2 dan 2-3 berada di luar rentang spesifikasi. Dalam hal ini lebih besar atau secara ukruan butirannya lebih kasar.

Tabel 2. Ringkasan hasil Pengujian Agregat Halus

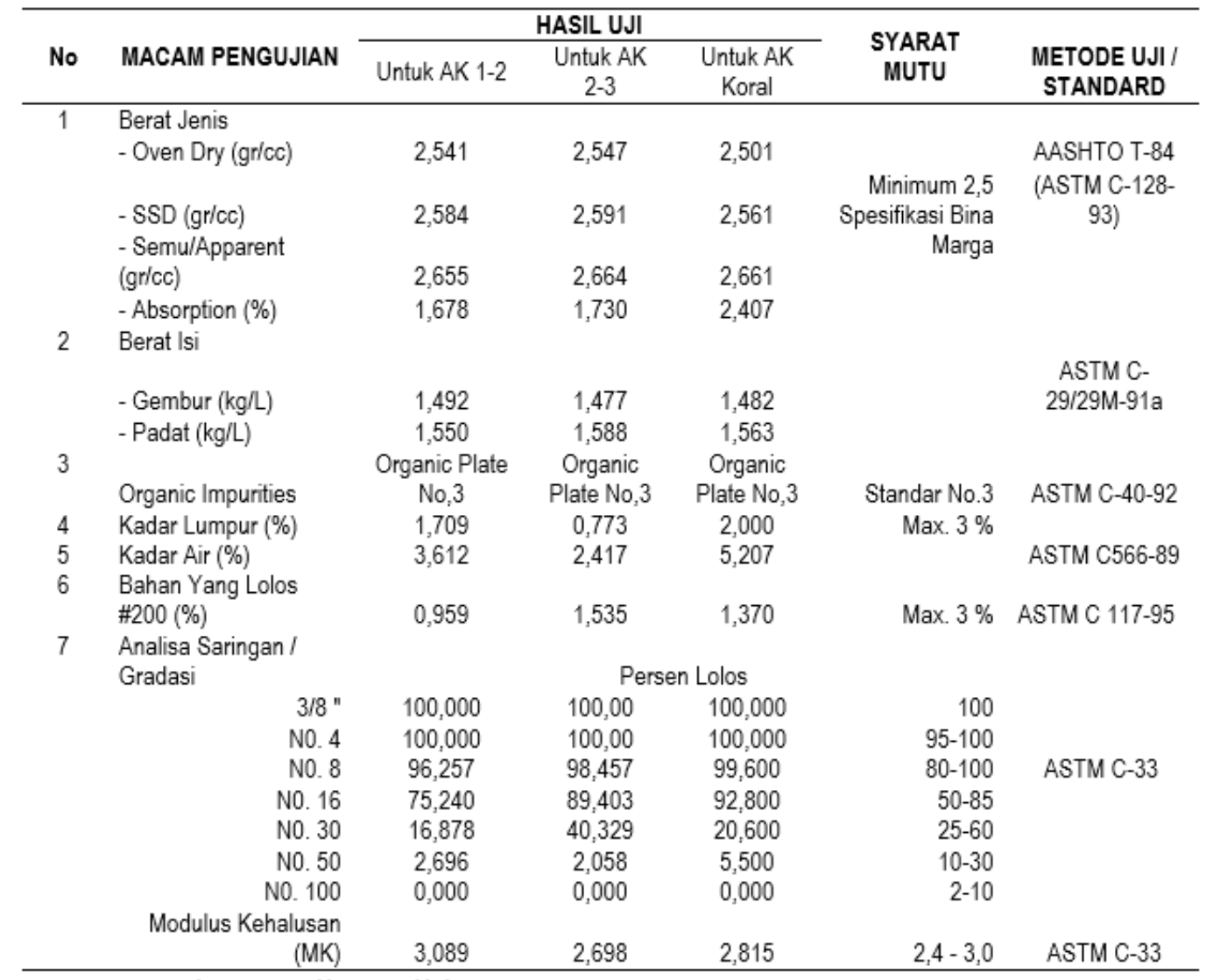

Sumber: Hasil Penelitian, 2017

Tabel 2. di atas menunjukkan bahwa untuk gradasi butiran, ketiga jenis pasir yang digunakan tidak sepenuhnya memenuhi spesifikasi. Semua agregat halus kurang dari 10\% yang lolos saringan \#50 (spesifikasi $10-30 \%$ ). Agregat 12 dan koral juga tidak memenuhi persyaratan persentase lolos saringan \#30. Hasil uji menunjukkan nilai yang kurang dari 25\% (persyaratan $25-60 \%$ ). Kemudian, agregat kasar 2-3 dan koral melebihi batasan untuk material lolos saringan \#16, masing-masing lolos sebanyak $89,403 \%$ dan $92,800 \%$ (syarat : $50-85 \%$ ).

Hasil uji kekerasan agregat kasar berupa impact test dan abrassion test menunjukkan nilai-nilainya masih dalam rentang spesifikasi. Agregat kasar Koral merupakan yang paling lemah dari ketiga macam agregat kasar tersebut, baik dari nilai abrasinya ataupun hasil uji impact test nya. Secara grafis perbandingan nilainilai tersebut dapat dilihat pada gambar berikut. 


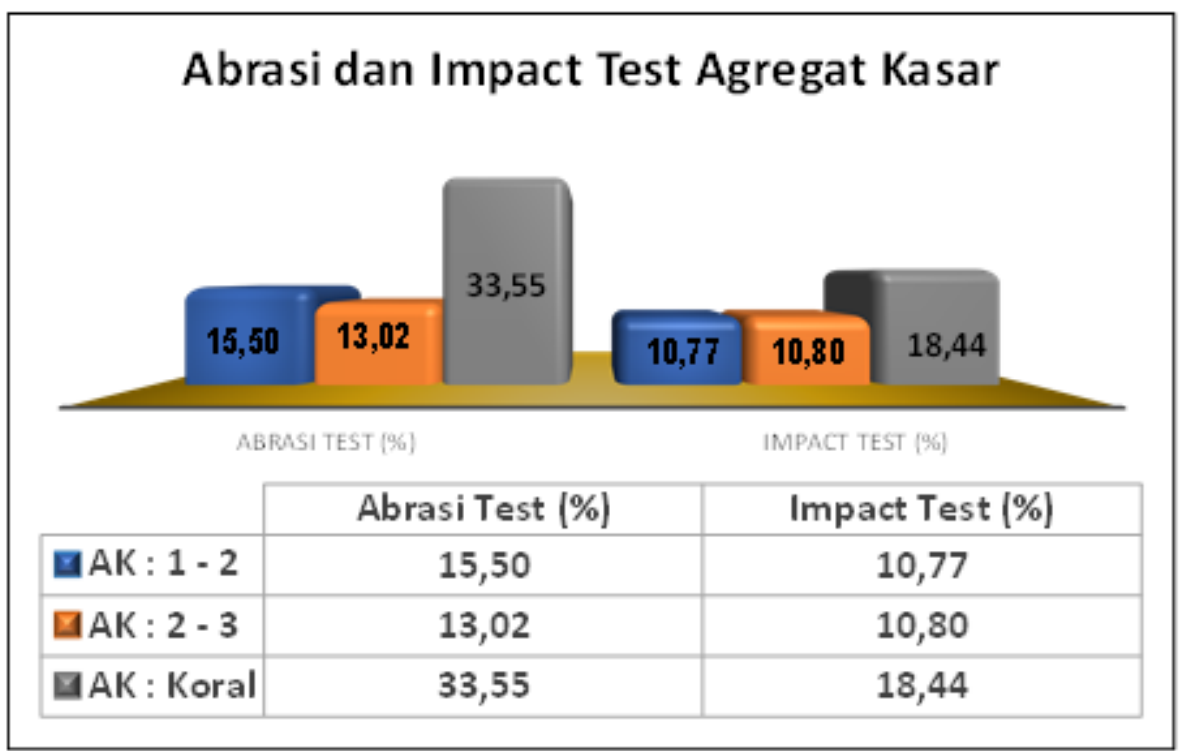

Gambar 1. Perbandingan hasil uji abrasi dan impak Agregat Kasar

Berat isi padat agregat kasar ukuran 2-3 beserta berat isi agregat halusnya merupakan yang paling besar nilainya dari masing-masing ketiga macam agregat kasar dan agregat halus. Perbandingna berat isi gembur dan padat untuk agregat kasar dan halus dapat dilihat pad gambar 2 berikut
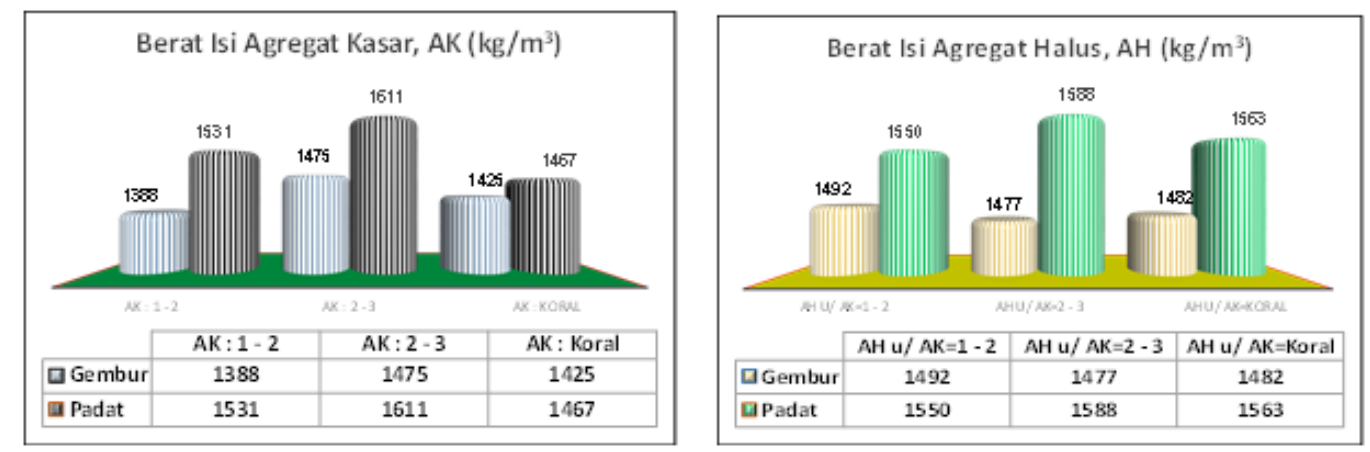

Gambar 2. Perbandingan berat isi gembur dan padat Agregat

Design Mix Formula (DMF) untuk ketiga mutu beton (K-125, K-175 dan K-225) dibuat menurut SNI 03-2834-2002, Tata cara pembuatan rencana campuran beton normal. Berdasarkan kriteria dalam standar tersebut, untuk mutu rencana dan ukuran agregat maksimum yang sama, akan menghasilkan komposisi material yang sama. Hal ini terlihat untuk komposisi material yang menggunakan agregat kasar batu pecah ukuran $1-2$ dan koral yang ukuran maksimum agregatnya juga 1- 2. Jumlah kebutuhan agregat kasar, agregat halus, semen maupun air pencampur jumahnya sama untuk kedua jenis agregat kasar tersebut. Untuk beton yang mengggunakan ukuran maksimum agregat kasar lebih besar, membutuhkan semen yang lebih sedikit. Demikian juga untuk faktor air semen. Penggunaan agregat kasar yang lebih besar memberikan fas yang lebih kecil dibanding beton dengan agregat kasar yang lebih kecil ukurannya. Secara grafik deskripsi di atas dapat dilihat pada gambar 3 (a) , (b) dan (c) berikut. 


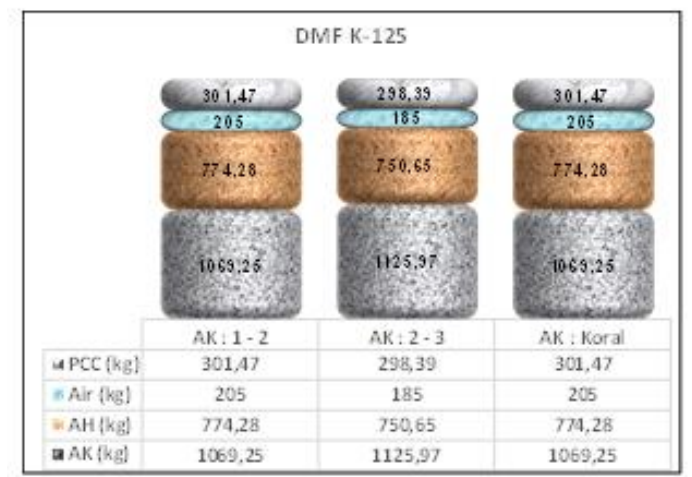

(a)

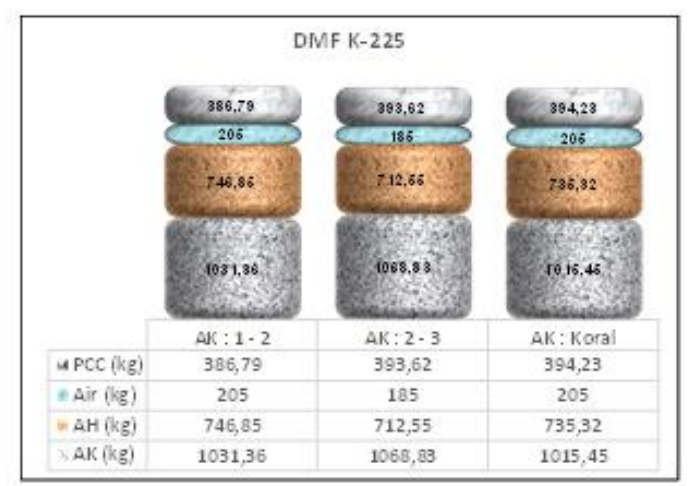

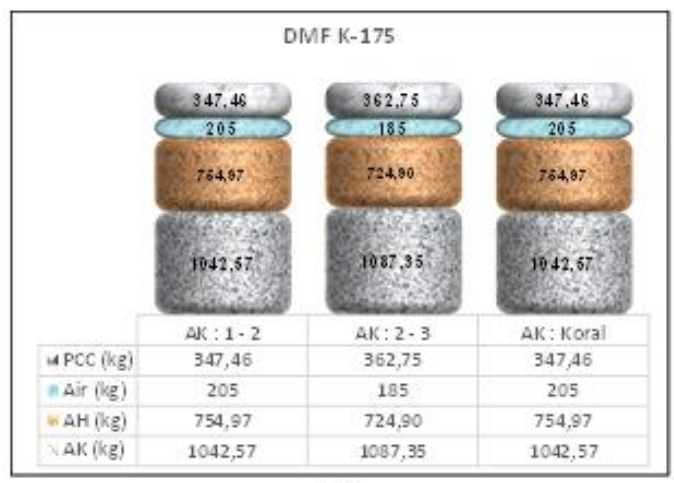

(b)

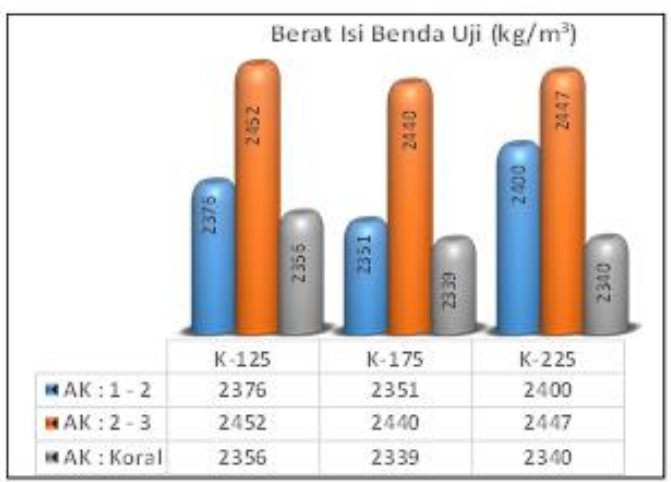

Gambar 3. Komposisi DMF dan Berat Isi Beton

Gambar 3(d) memperlihatkan perbandingan berat isi benda uji silinder beton. Terlihat ada korelasi antara berat isi agregat dengan berat isi beton. Sebagaimana pada gambar 4.2 bahwa agregat kasar ukuran 2-3 dan agregat halusnya memiliki bobot isi yang paling besar. Demikian juga pada berat isi beton. Silinder beton yang menggunakan agregat kasar ukuran 2-3 memiliki berat isi yang paling besar $\left(>2400 \mathrm{~kg} / \mathrm{m}^{3}\right)$. Sedangkan silinder beton dengan agregat kasar berupa koral memiliki berat isi yang paling kecil.

Secara statistik dalam perencanaan beton, nilai kuat tekan yang disyaratkan dan nilai kuat tekan target adalah sebagai berikut.

Tabel 3. Nilai kuat tekan yang diteliti

\begin{tabular}{llcc}
\hline $\begin{array}{l}\text { No } \\
\cdot\end{array}$ & $\begin{array}{l}\text { Kode } \\
\text { Mutu }\end{array}$ & $\begin{array}{c}\text { Kuat tekan yang } \\
\text { disyaratkan } \\
\left(\mathrm{kg} / \mathrm{cm}^{2}\right)\end{array}$ & $\begin{array}{c}\text { Kuat tekan target } \\
\left(\mathrm{kg} / \mathrm{cm}^{2}\right)\end{array}$ \\
\hline 1 & $\mathrm{~K}-125$ & 125 & 157 \\
2 & $\mathrm{~K}-175$ & 175 & 257 \\
3 & $\mathrm{~K}-225$ & 225 & 307 \\
\hline
\end{tabular}




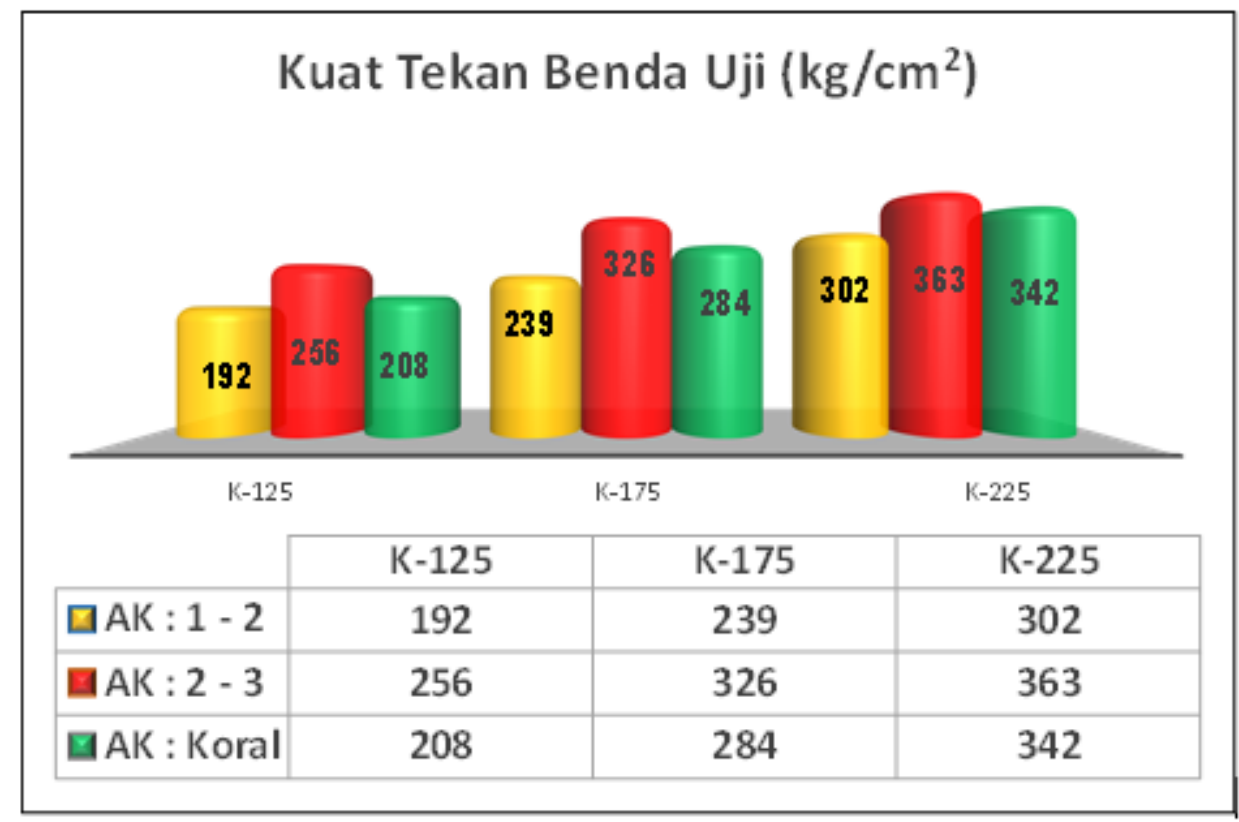

Gambar 4. Kuat tekan benda uji umur 28 hari

Hasil uji kuat tekan menunjukkan bahwa beton dengan agregat kasar batu pecah ukuran 1-2 tidak memenuhi kuat tekan yang ditargetkan untuk semua mutu rencana. Namun nilai tersebut masih memenuhi kuat tekan yang disyaratkan. Sedangkan untuk beton yang menggunakan agregat kasar batu pecah ukuran 2-3 dan koral sama-sama memenuhi kedua syarat kuat tekan tersebut. Beton dengan agregat kasar batu pecah ukuran 2-3 memiliki nilai kuat tekan tertinggi untuk semua mutu rencana

\section{SIMPULAN}

1. Agregat kasar berupa koral yang digunakan untuk mutu rencana beton sama tidak memenuhi persyaratan dalam gradasi butirnya. Gradasi butirnya tidak menerus, namun cenderung seragam.

2. Agregat halus yang digunakan untuk masing-masing agregat kasar semuanya tidak memenuhi persyaratan gradasi butirnya.

3. Hasil uji kuat tekan menunjukkan bahwa beton dengan agregat kasar batu pecah ukuran 2-3 memenuhi persyaratan baik syarat mutu maupun target mutu beton.

4. Meskipun agregat kasar batu pecah ukuran 1-2 secara nilai pemeriksaan laboratorium lebih bagus dari agregat kasar koral, namun kuat tekannya beton yang dihasilkannya lebih rendah dari beton yang menggunakan agregat kasar berupa koral.

\section{Saran}

1. Meskipun ada keterbatasan dalam pemilihan agregat di lapangan, namun diusahakan adanya suatu perlakuan terhadap agregat tersebut sehingga beton yang dihasilkan mempunyai kuat tekan sesuai yang diharapkan. Hal ini bisa dilakukan dengan mengontrol kekotoran agregat dengan cara pencucian sebelum digunakan.

2. Untuk mendapatkan hubungan yang lebih akurat, perlu dilakukan penelitian yang lebih spesifik atas variasi satu jenis material saja terhadap kuat tekan beton. 


\section{DAFTAR PUSTAKA}

ACI Manual of Concrete Practice Part 1, 1995

ASTM. Concrete and Aggregates. Annual Book of ASTM Standard Vol. 04.02. American Society for Testing and Materials. Philadelphia. 1993

Departemen Pekerjaan Umum. 2010. Pengendalian Mutu Pekerjaan Beton. Balai Jembatan dan Bangunan Pelengkap Jalan. Bandung.

Hulaila Fitria. 2008. Pengaruh Variasi Ukuran Agregat Halus Terhadap Kuat Tekan Beton (Tugas Akhir). Universitas Batanghari. Jambi.

Mulyono Tri. 2003. Teknologi Beton. Penerbit Andi Offset. Jakarta.

Nawy. E. G.. 1990. Beton Bertulang. Erlangga. Jakarta

PT. Semen Padang. 2012.Perkembangan Teknologi Semen Dan Beton Masa Kini.

SNI 03-1974-1990. Metode Pengujian Kuat Tekan Beton

SNI 03-2834-2002. Tata cara pembuatan rencana campuran beton normal

Sugianto. 2007. Kuat Tekan Benda Uji Silinder Beton Dengan Variasi Ukuran

Maksimum Agregat Kasar (Tugas Akhir). Universitas Batanghari. Jambi. 